\section{Differences in subcutaneous fat in breast- and formula-fed infants}

Infants who are fed overconcentrated artificial milk feeds, or who have cereals introduced into their diet before 6 weeks of age tend to have an excessive weight gain (Taitz and Harris, 1972) and are prone to develop hypertonic dehydration (Taitz and Byers, 1972). Since 1970, Sheffield mothers have been encouraged more positively to breast feed, and discouraged from feeding their infants overconcentrated feeds, or introducing cereals before 6 weeks of age. The purpose of this communication is to show that whereas solely formula-fed infants in Sheffield now have a similar weight gain to fully breast-fed infants, there is a difference in skinfold thickness between the two groups of infants at 6 weeks of age.

\section{Patients and methods}

315 Caucasian infants seen at the Jessop Hospital Well-Baby Clinic between 5 and 7 weeks of age were included in the study. Each was a singleton of $>2.5 \mathrm{~kg}$ birthweight, born between 37 and 42 weeks of gestation, and none had been ill. The mid-triceps and subscapular skinfold of each infant was measured (Tanner and Whitehouse, 1975) within the first 24 hours of life, and at 5-7 weeks of age. The measurement was taken when the pointer had stabilized because more prolonged application, as recommended by others (Brans et al., 1974), made the babies cry .

By careful questioning of the mother, the infants were divided into three groups: fully breast fed, infants fed only cows' milk formulae, and infants fed cows' milk formulae and cereals during the first 6 weeks of life. Cereal feeding was defined as being more than one teaspoon of cereal a day for longer than one week.

The actual weight gain and increase in skinfold thickness was calculated for each infant and corrected to the value which would have been observed at the age of 6 weeks. Allowance was made for sex, since males are known to have a more rapid postnatal growth and females a greater skinfold thickness at birth (Gampel, 1965).

\section{Results}

There was no significant difference in gestational age, birthweight, or skinfold thickness at birth between the three groups of male or female infants. The increase in the average of triceps and subscapular skinfold thicknesses and the weight gain over the first 6 weeks of life for infants who were breast fed, formulae fed, and for those fed formulae plus cereal are shown in the Table.

Breast-fed infants had a similar weight gain, and yet a significantly greater increase in skinfold thickness, than formula-fed infants at 6 weeks of age (P $<0.001$ for either males or females). Female infants who were fed formulae plus cereals had a greater weight gain than either breast- or formulafed infants $(P<0.05)$. The increase in skinfold thickness in infants fed formula plus cereal was intermediate between that of formula-fed and breast-fed male infants, and was greater than that of females who were breast fed $(P<0.005)$. The weight gain during the first 6 weeks of life in breastfed or formula-fed infants was greater in males than in females $(P<0.05)$.

\section{Discussion}

This study has shown that infants who are breast fed have a greater increase in subcutaneous fat

Table Mean $( \pm S E)$ weight gain and increase in skinfold thickness at 6 weeks, of infants fed in different ways

\begin{tabular}{|c|c|c|c|c|c|c|c|}
\hline \multirow[b]{2}{*}{$\therefore$} & \multirow{2}{*}{$\begin{array}{l}\text { No. of } \\
\text { patients }\end{array}$} & \multicolumn{3}{|c|}{ Body weight $(g)$} & \multicolumn{3}{|c|}{ Skinfold thickness $(\mathrm{mm})$} \\
\hline & & At birth & At 6 weeks & Increase & At birth & At 6 weeks & Increase \\
\hline \multicolumn{8}{|l|}{ Males } \\
\hline \multirow{3}{*}{$\begin{array}{l}\text { Breast fed } \\
\text { Bottle fed } \\
\text { Bottle and } \\
\text { cereal fed }\end{array}$} & 44 & $3620( \pm 81)$ & $4850( \pm 101)$ & $1230( \pm 58)$ & $4 \cdot 87( \pm 0 \cdot 14)$ & $6 \cdot 06( \pm 0 \cdot 2)$ & $1 \cdot 19( \pm 0 \cdot 03)$ \\
\hline & 84 & $3670( \pm 56)$ & $4870( \pm 66)$ & $1200( \pm 42)$ & $4 \cdot 76( \pm 0 \cdot 12)$ & $5 \cdot 49( \pm 0 \cdot 1)^{*}$ & $0.73( \pm 0.02) \ddagger$ \\
\hline & 28 & $3590( \pm 111)$ & $4900( \pm 139)$ & $1310( \pm 66)$ & $4 \cdot 73( \pm 0 \cdot 19)$ & $5 \cdot 65( \pm 0 \cdot 2)$ & $0.92( \pm 0.05) \ddagger$ \\
\hline \multicolumn{8}{|l|}{ Fernales } \\
\hline \multirow{3}{*}{$\begin{array}{l}\text { Breast fed } \\
\text { Bottle fed } \\
\text { Bottle and } \\
\text { cereal fed }\end{array}$} & 43 & $3550( \pm 76)$ & $4610( \pm 99)$ & $1060( \pm 50)$ & $4 \cdot 96( \pm 0 \cdot 16)$ & $6 \cdot 01( \pm 0 \cdot 2)$ & $1 \cdot 05( \pm 0 \cdot 03)$ \\
\hline & 89 & $3590( \pm 55)$ & $4610( \pm 66)$ & $1020( \pm 32)$ & $5 \cdot 02( \pm 0 \cdot 10)$ & $5 \cdot 49( \pm 0 \cdot 1) \dagger$ & $0.47( \pm 0.02) \ddagger$ \\
\hline & 27 & $3420( \pm 123)$ & $4640( \pm 135)$ & $1240( \pm 67)^{*}$ & $4 \cdot 65( \pm 0 \cdot 17)$ & $5 \cdot 89( \pm 0 \cdot 2)$ & $1 \cdot 24( \pm 0 \cdot 06) \dagger$ \\
\hline
\end{tabular}

Level of significance for comparison with breast-fed groups: ${ }^{*} \mathbf{P}<0.05 ;+P<0.01 ; \ddagger P<0.001$. 
during the first 6 weeks of postnatal life than infants who are fed cows' milk formulae, despite a similar weight gain in the two groups. Measurements made by skinfold calipers indicate the amount of subcutaneous fat present (Lee and $\mathrm{Ng}, 1965$ ). Use of the average of triceps and subscapular skinfold thicknesses reduces operator error and gives a more reproducible value than use of triceps or subscapular skinfold alone (unpublished).

The fatty acid composition of human milk is very different from that of cows' milk, and feeding human infants on cows' milk formulae leads to differences in the fatty acid composition of subcutaneous fat (Widdowson et al., 1975). The present study shows that feeding human infants on cows' milk also leads to differences in the quantity of subcutaneous fat. As the weight gain was similar in both breast-fed and formulae-fed infants, the lesser amounts of subcutaneous fat in formulae-fed infants must have been counterbalanced by either an increase in lean body mass, or an increase in deeper depot fats.

It seems to be important to exclude infants who have been fed cereals from studies of this type. Male infants who were fed cereals plus milk formulae had an insignificantly greater increase in body weight but an increase in skinfold thickness which was intermediate between breast- and formula-fed infants. The difficulties of interpreting data from infants who have been fed cereals are highlighted in females in whom cereal supplementation was such that the weight gain was significantly greater than in either breast- or formula-fed infants, resulting in a significantly greater increase in skinfold thickness.

The questions arising from the observations in this study warrant futher research in man and animals to clarify the mechanisms by which adipose tissue develops as a function of feeding regimens with different types of milk.

\section{Summary}

During the first 6 weeks of life, 87 breast-fed infants had a significantly greater increase in skinfold thickness than 173 infants fed only with artificial milk formulae. The two groups were similar in respect of racial origin, gestational age, birthweight, and weight gain in the first 6 weeks of life. These findings show that formula-fed infants have a different distribution of body fat from breast-fed infants.

I thank Drs. J. A. Black and L. S. Taitz for permission to include their patients in this study, and Professor R. D. G. Milner for advice and encouragement.

\section{References}

Brans, Y. W., Sumners, J. E., Dweck, H. S., and Cassady, G. (1974). A noninvasive approach to body composition in the neonate. Dynamic skinfold measurements. Pediatric Research, 8, 215-222.

Gampel, B. (1965). Relation of skinfold thickness in the neonate to sex, length of gestation, size at birth, and maternal skinfold. Human Biology, 37, 29-37.

Lee, M. M. C., and Ng, C. K. (1965). Postmortem studies of skinfold caliper measurement and actual thickness of skin and subcutaneous tissue. Human Biology, 37, 91-103.

Taitz, L. S., and Byers, H. S. (1972). High calorie/osmolar feeding and hypertonic dehydrates. Archives of Disease in Childhood, 47, 257-260.

Taitz, L. S., and Harris, F. (1972). Accelerated weight gain in artificially fed babies. Acta Paediatrica Scandinavica, 61, 499-500.

Tanner, J. M., and Whitehouse, R. H. (1975). Revised standards for triceps and subscapular skinfolds in British children. Archives of Disease in Childhood, 50, 142-145.

Widdowson, E. M., Dauncey, M. J., Gairdner, D. M. T., Jonxis, J. H. P., and Pelikan-Filipkova, M. (1975). Body fat of British and Dutch infants. British Medical Journal, 1, 653-655.

\section{J. R. OAKLEY}

Stephenson Unit, Children's Hospital, Western Bank, Sheffield S10 2TH. 